\title{
CDK12 wt Allele
}

National Cancer Institute

\section{Source}

National Cancer Institute. CDK12 wt Allele. NCI Thesaurus. Code C101096.

Human CDK12 wild-type allele is located in the vicinity of $17 q 12$ and is approximately 73 $\mathrm{kb}$ in length. This allele, which encodes cyclin-dependent kinase 12 protein, plays a role in the modulation of protein phosphorylation. Chromosomal deletions within the 17q12 region can lead to out of frame fusions of this gene and the ERBB2 gene and may be associated with gastric cancer. 